\title{
PENINGKATAN PENJUALAN KERIPIK PISANG SETELAH MEMPEROLEH SERTIFIKAT HALAL SERTA PERILAKU KONSUMENNYA DI KOTA BANDAR LAMPUNG
}

\author{
(The Increased Sales of Banana Chips after Obtaining Halal Certificate and Consumer Behavior \\ in Bandar Lampung City)
}

Elsa Fitriana, Yaktiworo Indriani, Begem Viantimala

Jurusan Agribisnis, Fakultas Pertanian, Universitas Lampung, Jl. Prof. Dr. Soemantri Brojonegoro No. 1 Bandar Lampung, 35145,e-mail: yaktiworo.indriani@fp.unila.ac.id

\begin{abstract}
This study aims to study the halal certification process of banana processed products at the Institute for Food, Drugs, and Cosmetics Studies of The Indonesian Ulama Council (LPPOM MUI) Lampung Province, to find out the increase in sales of banana chips after obtaining a halal certificate, and to explore consumer behavior of Lampung banana chips branded KPS, PD. AS, and KPKK. The research is conducted by survey method. Data collection was conducted in March 2019 in which 45 people were selected by using accidental sampling. The data are analyzed by descriptive analysis and Attitude model of Multiatribute Fishbein. The halal certification process carried out by LPPOM MUI Lampung Province on banana chips agroindusty has several online steps on web regs.e-lppommui.org. The increase in sales after obtaining a halal certificate is an increase in the number of production with the turnover reaching 40 percent. When purchasing banana chips, halal is highly considered by consumers. Consumers at KPS, PD. AS, and KPKK are satisfied and may repurchase.
\end{abstract}

Key words: banana chips, consumers, halal certificate

\section{PENDAHULUAN}

Agribisnis merupakan suatu kesatuan kegiatan usaha yang meliputi salah satu atau keseluruhan dari mata rantai produksi, pengolahan hasil dan pemasaran yang ada hubungannya dengan pertanian dalam arti luas. Sebagai penggerak pembangunan pertanian, agribisnis dan agroindustri diharapkan dapat memainkan peranan penting dalam kegiatan pembangunan daerah. Suatu perusahaan dalam melaksanakan proses produksi membutuhkan faktor-faktor yang dapat menunjang tercapainya tujuan perusahaan. Faktorfaktor tersebut adalah bahan baku, modal, mesin dan manusia (Soekartawi 2005).

Buah-buahan banyak digunakan oleh agroindustri sebagai bahan baku utama, salah satunya adalah buah pisang. Pisang merupakan buah yang berpotensi tinggi dalam pengembangan produk olahan agroindustri. Keripik pisang, sale pisang, bolu pisang, dan pie pisang adalah beberapa produk makanan ringan yang menggunakan pisang sebagai bahan baku utama. Provinsi Lampung merupakan daerah potensial dalam pengembangan komoditas buah pisang. Jumlah produksi pisang di Provinsi Lampung menempati posisi pertama pada tahun 2016 dengan jumlah sebesar 1.937.348 ton.
Agroindustri yang memproduksi olahan pisang banyak ditemui di Kota Bandar Lampung yang merupakan pusat aktivitas ekonomi masyarakat. Seiring dengan perkembangan agroindustri, suatu agroindustri atau perusahaan dituntut untuk dapat menjamin keamanan dan kehalalan produk makanan yang dihasilkan dengan memiliki sertifikat halal pada produknya.

Konsumen yang beragama Islam saat membeli produk perlu memperhatikan kehalalan produk yang akan dikonsumsi. Perusahaan yang belum memiliki sertifikat halal memberikan ketidaknyamanan bagi konsumen jika ingin membeli dan mengonsumsi keripik pisang. Sertifikat halal yang dimiliki agroindustri keripik pisang mempengaruhi perilaku konsumen, yaitu sikap konsumen yang diukur menggunakan atribut produk dan proses pengambilan keputusan pembelian yang terdiri dari pengenalan kebutuhan, pencarian informasi, evaluasi alternatif, keputusan pembelian, dan evaluasi pasca pembelian. Sertifikat halal yang dimiliki produsen menjadi hal penting jika ingin menciptakan dan menjual produk makanan. Peraturan yang bersifat teknis yang mengatur tentang Jaminan Produk Halal (JPH) di Indonesia adalah Undang-Undang Republik Indonesia No. 33 Tahun 2014. Pada pasal 4 dinyatakan bahwa produk yang masuk, beredar, 
dan diperdagangkan di wilayah Indonesia wajib bersertifikat halal.

Keripik pisang saat ini banyak diproduksi dan menjadi produk unggulan oleh-oleh khas Lampung. Terdapat 16 perusahaan makanan ringan berbasis pisang di Kota Bandar Lampung. Beberapa agroindustri atau perusahaan makanan ringan sudah bersertifikat halal, namun banyak agroindustri atau perusahaan yang belum memiliki sertifikat halal pada produknya. Ada enam agroindustri keripik pisang di Kota Bandar Lampung yang telah memiliki sertifikat halal, yaitu agroindustri Keripik Pisang Suseno, Keripik Pisang Kepok Kresna, PD. Aroma Sejati, Keripik Ante, Irawan Chips, dan UD Jaya Makmur. Berdasarkan uraian tersebut dilakukan penelitian dengan tujuan untuk mempelajari proses sertifikasi halal produk keripik pisang yang dilakukan di Lembaga Pengkajian Pangan Obat-obatan dan Kosmetika Majelis Ulama Indonesia (LPPOM MUI) Provinsi Lampung, mengetahui peningkatan penjualan keripik pisang setelah memperoleh sertifikat halal (produk, harga, tempat, promosi, dan omzet) serta mengetahui perilaku konsumennya.

\section{METODE PENELITIAN}

Penelitian ini menggunakan metode survai. Lokasi dipilih secara sengaja (purposive) dengan pertimbangan jumlah pengunjung terbanyak per hari dan produk keripik pisang sudah bersertifikat halal. Pengambilan data dilakukan pada tiga agroindustri keripik pisang yang berada di Kota Bandar Lampung, yaitu Keripik Pisang Suseno (KPS), Perusahaan Dagang Aroma Sejati (PD AS) dan Keripik Pisang Kepok Kresna (KPKK). Jumlah pengunjung per hari pada masing-masing agroindustri adalah 45 orang pada KPS, 35 orang pada PD. AS, dan 30 orang pada KPKK.

Jenis data yang digunakan pada penelitian ini adalah data primer dan sekunder. Data primer merupakan data yang dikumpulkan melalui wawancara secara langsung menggunakan kuesioner meliputi produksi keripik pisang, bauran pemasaran, omzet, sikap konsumen, dan proses pengambilan keputusan pembelian. Data sekunder adalah data yang diperoleh dari lembaga-lembaga yang terkait dengan penelitian ini. Data instansi yang digunakan adalah Dinas Perindustrian Kota Bandar Lampung, data Badan Pusat Statistik, dan
LPPOM MUI Provinsi Lampung. Pengambilan data dilakukan pada bulan April 2019. Pengambilan sampel menggunakan accidental sampling. Menurut Sugiyono (2009), accidental sampling adalah teknik penentuan sampel berdasarkan kebetulan, yaitu konsumen yang secara kebetulan bertemu dengan peneliti dapat digunakan sebagai sampel dan dipandang orang itu cocok sebagai sumber data. Penentuan jumlah sampel menggunakan rumus Isaac dan Michael dalam Andela (2019) dengan rumus:

$\mathrm{n}=\frac{\mathrm{NZ} \mathrm{Z}^{2} \mathrm{~S}^{2}}{\mathrm{Nd}^{2}+\mathrm{Z}^{2} \mathrm{~S}^{2}}$

Keterangan:

$\mathrm{n} \quad=$ Jumlah sampel

$\mathrm{N}=$ Jumlah populasi

$\mathrm{S}^{2} \quad=$ Variasi sampel $(5 \%=0,05)$

$\mathrm{Z}=$ Tingkat kepercayaan $(95 \%=1,96)$

$\mathrm{d}=$ Derajat kesalahan $(5 \%=0,05)$

Jumlah populasi yang diperoleh pada agroindustri KPS, PD. AS, dan KPKK sebanyak 110 orang. Jumlah tersebut diperoleh berdasarkan jumlah ratarata pengunjung atau konsumen perhari. Berdasarkan perhitungan dengan menggunakan rumus tersebut maka jumlah sampel adalah:

$\mathrm{n}=\frac{110(1,96)^{2}(0,05)}{110(0,05)^{2}+(1,96)^{2}(0,05)}=45,2359 \approx 45$

Menurut Sufren dan Natanael (2013), uji validitas merupakan suatu alat ukur yang valid dan dapat menjalankan fungsi ukurnya dengan tepat, juga memiliki kecermatan tinggi dalam mengukur valid atau tidaknya suatu kuesioner. Nilai validitas dapat dikatakan sesuai dan baik jika nilai corrected item dari total correlation dengan nilai di atas 0,20. Suatu instrumen dikatakan reliabel jika nilai cronbach alpha lebih besar dari 0,60 (Ghozali2002).

Pengumpulan data dilakukan menggunakan kuesioner yang sudah diuji validitas dan reliabilitasnya. Uji validitas dan reliabilitas dilakukan terhadap kuesioner yang telah diisi oleh 30 responden untuk mengetahui apakah data sudah (valid) dan (reliable). Data uji validitas tingkat kepentingan dan kepercayaan keripik pisang pada agroindustri KPS, PD AS, dan KPKK dapat dilihat pada Tabel 1. 
Tabel 1. Hasil uji validitas tingkat kepentingan dan kepercayaan terhadap keripik pisang bersertifikat halal pada agroindustri KPS, PD AS, dan KPKK

\begin{tabular}{clcc}
\hline \multirow{2}{*}{ No. } & \multirow{2}{*}{$\begin{array}{c}\text { Variabel } \\
\text { Indikator }\end{array}$} & $\begin{array}{c}\text { Tingkat } \\
\text { Kepentingan }\end{array}$ & $\begin{array}{c}\text { Tingkat } \\
\text { Kepercayaan }\end{array}$ \\
\cline { 3 - 4 } & & Corrected Item-Total Correlation \\
\hline 1. & Harga & 0,29 & 0,49 \\
2. & Rasa & 0,44 & 0,74 \\
3. & Label halal & 0,21 & 0,79 \\
4. & Kemasan & 0,73 & 0,65 \\
5. & Kerenyahan & 0,28 & 0,65 \\
6. & Expired & 0,38 & 0,57 \\
& Date & 0,38 \\
\hline
\end{tabular}

Berdasarkan hasil uji validitas pada Tabel 1 menunjukkan bahwa enam atribut yang digunakan untuk mengukur tingkat kepentingan dan tingkat kepercayaan terhadap keripik pisang pada agroindustri KPS, PD AS, dan KPKK sudah valid karena nilai corrected item dari total correlation di atas 0,20. Hasil uji reliabilitas tingkat kepentingan dan tingkat kepercayaan atribut keripik pisang pada agroindustri KPS, PD AS, dan KPKK memiliki nilai cronbach's alpha tingkat kepentingan atribut sebesar 0,65 dan cronbach's alpha tingkat kepercayaan sebesar 0,85. Hasil tersebut menunjukkan bahwa semua pertanyaan yang diajukan di dalam kuesioner dinyatakan reliabel karena nilainya di atas 0,60 .

Analisis deskriptif digunakan untuk menjelaskan proses sertifikasi halal yang dilakukan di LPPOM MUI Provinsi Lampung, menjelaskan peningkatan penjualan keripik pisang setelah memperoleh sertifikat halal, dan menjelaskan tahap-tahap proses pengambilan keputusan pembelian (pengenalan kebutuhan, pencarian informasi, evaluasi alternatif, keputusan pembelian, dan evaluasi pasca pembelian). Analisis ini bertujuan untuk menganalisis data dengan cara mendeskripsikan atau menggambarkan data yang diperoleh dari hasil penelitian.

Analisis model Sikap Multiatribut Fishbein digunakan untuk mengetahui perilaku konsumen yang ditinjau dari sikap konsumen. Model tersebut menggambarkan bahwa sikap konsumen terhadap suatu produk atau merek sebuah produk ditentukan oleh dua hal, yaitu kepercayaan terhadap atribut yang dimiliki suatu produk atau merek (komponen bi) dan evaluasi pentingnya atribut dari produk tersebut (komponen ei), (Sumarwan 2011), diformulasikan dalam rumus:

$$
\mathrm{A}_{0}=\sum_{\mathrm{i}=1}^{\mathrm{n}} \text { biei }
$$

Keterangan:

$\mathrm{A}_{\mathrm{o}}=$ Sikap terhadap suatu objek

bi = Kekuatan kepercayaan bahwa objek memiliki atribut i

ei $=$ Evaluasi terhadap atribut $\mathrm{i}$

$\mathrm{n}=$ Jumlah atribut $\mathrm{i}$

Pada model Multiatribut Fishbein variabel $\mathrm{A}_{\mathrm{o}}$ adalah sikap konsumen terhadap produk keripik pisang yang diperoleh melalui hasil perkalian setiap skor evaluasi (ei) dengan skor kepercayaan (bi) berdasarkan sikap konsumen terhadap produk keripik pisang. Komponen (ei) adalah evaluasi kepentingan aribut-atribut yang terdapat pada produk keripik pisang yang diukur dengan skor (5), (4), (3), (2), (1). Skor (5) sangat penting, (4) penting, (3) cukup penting, (2) tidak penting dan (1) sangat tidak penting. Komponen bi adalah tingkat kepercayaan konsumen terhadapatributatribut produk keripik pisang. Skor pengukuran terhadap kepercayaan (bi) sama dengan pengukuran skor evaluasi ei. Atribut produk yang digunakan adalah harga, rasa, label halal, kemasan, kerenyahan, dan expired date.

\section{HASIL DAN PEMBAHASAN}

\section{Prosedur Pembuatan Sertifikasi Halal}

Sertifikat halal merupakan fatwa tertulis yang diterbitkan oleh Majelis Ulama Indonesia (MUI) untuk produk yang telah dinyatakan halal setelah melalui berbagai proses dan rapat. Lembaga yang mengeluarkan sertifikasi halal adalah Lembaga Pengkajian Pangan, Obat-obatan dan Kosmetik Majelis Ulama Indonesia (LPPOM MUI).

Perusahaan yang ingin memiliki sertifikat halal harus melakukan pendaftaran secara online melalui web regs.e-lppommui.org kemudian melakukan eHalal registrasi dengan CEROL. Berikut ini adalah prosedur yang ditentukan oleh LPPOM MUI dalam proses pembuatan sertifikat halal online bagi agroindustri pengolahan keripik pisang (LPPOM MUI 2014).

a. Perusahaan membuka regs.e-lppommui.org.

b. Sign up dan menulis profil perusahaan seperti nama, alamat, dan contact person perusahaan. Penulisan profil perusahaan harus benar karena data yang tercetak di sertifikat halal adalah data yang sudah diinput langsung oleh perusahaan. 
c. Klik sign up untuk mendapatkan akun, kemudian tulis username dan password yang sudah dibuat oleh perusahaan yang mendaftar.

d. Registrasi berdasarkan kelompok produk, tipe dan status registrasi.

e. Melakukan pembayaran registrasi, dapat dilakukan dengan dua cara yaitu tunai dan transfer.

f. Approve pembayaran registrasi oleh bagian keuangan LPPOM MUI Provinsi Lampung.

g. Upload dokumen meliputi data perusahaan, dokumen halal, data produk, data bahan, dan data matriks produk di cerol.

h. Dilakukan pemeriksaan kecukupan dokumen oleh bagian Auditing dan $\mathrm{SJH}$, kemudian perusahaan melakukan monitoring pre-audit.

i. Pembuatan akad oleh bagian keuangan LPPOM MUI Provinsi Lampung, kemudian dilakukan pembayaran akad oleh perusahaan.

j. Approve pembayaran akad oleh bagian keuangan kemudian dilakukan audit.

k. LPPOMMUI Provinsi Lampung akan memberitahukan perusahaan mengenai jadwal audit. Tim Auditor akan melakukan pemeriksaan atau audit ke lokasi produsen dan pada saat audit perusahaan harus dalam keadaan memproduksi produk yang disertifikasi, pemeriksaan (audit) meliputi:

1) Manajemen produsen dalam menjamin kehalalan produk SJH. Pemeriksaan dokumen-dokumen spesifikasi yang menjelaskan asal-usul bahan, komposisi dan proses pembuatannya dan/atau sertifikat halal pendukungnya, dokumen pengadaan dan penyimpanan bahan, formula produksi serta dokumen pelaksanaan produksi halal secara keseluruhan.

2) Observasi lapangan yang mencakup proses produksi secara keseluruhan mulai dari penerimaan bahan, produksi, pengemasan dan penggudangan serta penyajian untuk restoran/catering/outlet.

3) Keabsahan dokumen dan kesesuaian secara fisik untuk setiap bahan harus terpenuhi. Hasil pemeriksaan/audit dan hasil laboratorium (bila diperlukan) dievaluasi dalam Rapat Auditor LPPOM MUI Provinsi Lampung. Hasil audit yang belum memenuhi persyaratan diberitahukan kepada perusahaan melalui audit memorandum. Jika telah memenuhi persyaratan, auditor akan membuat laporan hasil audit guna diajukan pada Sidang Komisi Fatwa MUI untuk diputuskan status kehalalannya.

1. Laporan hasil audit disampaikan oleh Pengurus LPPOM MUI Provinsi Lampung dalam Sidang
Komisi Fatwa MUI pada waktu yang telah ditentukan.

m. Sidang Komisi Fatwa MUI dapat menolak laporan hasil audit jika dianggap belum memenuhi semua persyaratan yang telah ditentukan dan kemudian akan memberitahukannya pada perusahaan.

n. Sertifikat Halal dikeluarkan oleh MUI setelah ditetapkan status kehalalannya oleh Komisi Fatwa MUI.

o. Sertifikat Halal diunggah oleh LPPOM MUI dan kemudian bisa diunduh oleh perusahaan.

p. Sertifikat Halal berlaku selama dua tahun sejak tanggal penetapan fatwa.

Setelah perusahaan memperoleh sertifikat halal maka memiliki kewenangan untuk mencantumkan label halal pada produknya sebagai tanda kehalalan dari produk yang dihasilkan. Perusahaan berkewajiban membuat laporan audit internal setiap enam bulan sekali.

\section{Peningkatan Penjualan Setelah Memperoleh Sertifikat Halal}

Jumlah produksi keripik pisang pada agroindustri KPS, PD. AS, dan KPKK mengalami perubahan setelah mendapatkan sertifikat halal. Setiap satu kali produksi agroindustri KPS dapat menghabiskan satu ton buah pisang segar. Agroindustri KPS melakukan produksi sebanyak 2-3 kali dalam seminggu dengan jumlah keripik pisang yang dihasilkan sebanyak $500 \mathrm{~kg}$ per produksi. Perbedaan jumlah produksi di KPS sebesar 30 persen, dari $700 \mathrm{~kg}$ menjadi satu ton. Agroindustri PD. AS setiap produksi/hari membutuhkan $115 \mathrm{~kg}$ pisang muli dan $150 \mathrm{~kg}$ pisang kepok. Produksi dilakukan 3-4 kali per minggu dengan hasil $50 \mathrm{~kg}$ keripik pisang muli dan $40 \mathrm{~kg}$ keripik pisang kepok. Jumlah produksi meningkat sebesar 40 persen, dari $90-100 \mathrm{~kg}$ menjadi $150 \mathrm{~kg}$ pisang kepok. Agroindustri KPKK menghabiskan 100-150 kg keripik pisang setengah matang per produksi. Agroindustri KPKK melakukan produksi sebanyak 2-3 kali per minggu dengan jumlah keripik pisang yang dihasilkan sebanyak $100 \mathrm{~kg}$ per produksi. Setelah memiliki sertifikat halal, kenaikan terjadi sebesar 40 persen dari $60 \mathrm{~kg}$ menjadi $100 \mathrm{~kg}$ per produksi.

Perubahan yang terjadi pada penjualan setelah memperoleh sertifikat halal pada produk keripik pisang pada agroindustri KPS, PD. AS, dan KPKK adalah sebagai berikut. 
a. Produk

Produk yang dihasilkan agroindustri KPS adalah keripik pisang dengan empat varian rasa, yaitu manis, asin, cokelat, dan keju. Produk yang dihasilkan pada PD. AS adalah keripik pisang dengan 13 varian rasa. Varian rasa tersebut diantaranya adalah manis, asin, cokelat, keju, barbeque, green tea, balado, chocco coffee, susu, melon, strawberry, mocca, dan durian. Produk yang dihasilkan agroindustri KPKK adalah keripik pisang dengan 13 varian rasa, yaitu cokelat, keju, melon, stroberi, durian, mocca, balado, balado hijau, tiramisu, green tea, sapi panggang, asin, dan manis. Setelah memiliki sertifikat halal, KPS, PD. AS, dan KPKK tidak menambah varian rasa baru pada produk keripik pisangnya, karena pemilik hanya ingin mempertahankan kualitas varian rasa yang sudah ada. Adanya sertifikat halal tidak memberikan perubahan yang besar pada keragaman produk keripik pisang yang dihasilkan.

b. Harga

Harga keripik pisang pada agroindustri KPS, PD. AS, dan KPKK tidak berbeda sebelum dan sesudah bersertifikat halal, pemilik masih menggunakan harga yang sudah ditetapkan sebelumnya. Perubahan harga terjadi bila bahan baku yang digunakan sulit diperoleh dan mengalami kenaikan harga. Harga keripik pisang berkisar antara Rp10.000 - Rp55.000.

c. Tempat

Sebelum memiliki sertifikat halal, agroindustri KPS, PD. AS, dan KPKK hanya menjual produknya di toko sendiri. Setelah memiliki sertifikat halal produknya dapat dijual di bandara, hotel, dan beberapa supermarket yang ada di Kota Bandar Lampung dan sekitarnya. Agroindustri KPS mengalami perluasan pasar sebesar 50 persen, mitra yang menjalin kerjasama adalah Toko oleh-oleh di Teluk Betung, Chandra Mart, Gelalel, Manisan Yenyen, Manisan Lampung, Kantin Bandara Raden Intan, dan Branti Mart. Perluasan pasar agroindustri PD. AS terjadi sebesar 40 persen, mitra yang menjalin kerjasama yaitu Chandra Mart, Banana Foster, Transmart, Hotel Raden Intan, Cafe Pojok, Toko oleh-oleh di sekitar Bandar Lampung dan Pelabuhan Bakauhueni. Perluasan pasar agroindustri KPKK sebesar 50 persen sejak pertama berdiri, mitra yang menjalin kerjasama yaitu Chandra Mart, Hypermart, Banana Foster, Fitrinop, 212 Mart, Surya, Jaya Bakery, PB Swalayan, Kantin Bandara Raden Intan, dan Toko oleh-oleh di Kota Bandar Lampung dan sekitarnya. d. Promosi

Promosi yang dilakukan agroindustri KPS, PD. AS, dan KPKK semakin luas, sebelum produknya memiliki sertifikat halal hanya melakukan promosi dari mulut ke mulut. Saat ini melakukan promosi menggunakan banner dan menjual produknya secara online pada beberapa market place.

e. Omzet

Menurut Swastha (2005), salah satu faktor yang mempengaruhi besar kecilnya omzet adalah kemampuan perusahaan untuk mengelola produknya. Perubahan omzet yang terjadi padaagroindustri KPS, PD. AS, dan KPKK sejalan dengan pernyataan tersebut, tiga agroindustri tersebut sudah mengelola dengan baik produknya dengan memiliki sertifikat halal. PD. AS mengalami peningkatan omzet sesudah memiliki sertifikat halal. Kenaikan omzet tersebut mencapai 40 persen dari sebelumnya. Kenaikan omzet di KPS sebesar 30-40 persen. Jumlah omzet yang diperoleh KPKK setelah memiliki sertifikat halal mencapai 50 persen.

\section{Sikap Konsumen}

Sikap konsumen dalam pengambilan keputusan pembelian keripik pisang ditentukan oleh beberapa atribut, yaitu harga, rasa, label halal, kemasan, kerenyahan, dan expired date. Atribut keripik pisang dengan total skor sikap tertinggi adalah expired date dengan nilai rata-rata sebesar 20,68 pada KPS, 21,38 pada PD. AS, dan 22,89 pada KPKK. Atribut keripik pisang dengan total skor sikap terendah adalah kemasan pada KPS dengan skor 13,83 dan atribut harga pada PD. AS dan KPKK dengan skor 16,40 dan 16,17. Hal ini menunjukkan bahwa atribut expired date dinilai paling penting oleh konsumen pada saat membeli keripik pisang. Tanggal kadaluarsa akan menentukan konsumen dalam melakukan pembelian, karena dengan melihat tanggal kadaluarsa konsumen akan mengetahui sampai kapan batas konsumsi suatu produk.

Sikap konsumen merupakan hasil perkalian antara evaluasi atribut kepentingan (ei) dan atribut kepercayaan (bi). Hasil perhitungan model Sikap Multiatribut Fishbein diketahui bagaimana sikap konsumen (Ao) terhadap keripik pisang di agroindustri KPS, PD. AS, dan KPKK. Atribut dengan skor tertinggi dapat memberikan pengaruh yang sangat positif terhadap sikap konsumen. Hasil perhitungan sikap konsumen (Ao) terhadap atribut keripik pisang dapat dilihat pada Tabel 2. 
Tabel 2. Perhitungan sikap (Ao) terhadap atribut keripik pisang bersertifikat halal pada agroindustri KPS, PD. AS dan KPKK

\begin{tabular}{|c|c|c|c|c|c|c|c|c|}
\hline \multirow{2}{*}{ No. } & \multirow{2}{*}{ Atribut } & \multirow{2}{*}{ ei } & \multicolumn{2}{|c|}{ KPS } & \multicolumn{2}{|c|}{ PD. AS } & \multicolumn{2}{|c|}{ KPKK } \\
\hline & & & bi & ei.bi & bi & ei.bi & bi & ei.bi \\
\hline 1. & Harga & 4,53 & 3,50 & 15,86 & 3,62 & 16,40 & 3,57 & 16,17 \\
\hline 2. & Rasa & 4,80 & 4,11 & 19,73 & 4,15 & 19,92 & 4,36 & 20,93 \\
\hline 3. & Label Halal & 4,56 & 4,17 & 19,02 & 4,54 & 20,70 & 4,71 & 21,48 \\
\hline 4. & Kemasan & 4,02 & 3,44 & 13,83 & 4,38 & 17,61 & 4,71 & 18,93 \\
\hline 5. & Kerenyahan & 4,49 & 4,00 & 17,96 & 4,15 & 18,63 & 4,50 & 20,21 \\
\hline 6. & Expired Date & 4,71 & 4,39 & 20,68 & 4,54 & 21,38 & 4,86 & 22,89 \\
\hline Ao & & & & 107,06 & & 114,65 & & 120,61 \\
\hline
\end{tabular}

Data pada Tabel 2 menunjukkan bahwa total sikap konsumen (Ao) keripik pisang pada agroindustri KPKK merupakan yang tertinggi yaitu 120,61 dibandingkan total sikap konsumen (Ao) keripik pisang pada agroindustri PD. AS dan KPKK. Secara berurutan total skor sikap atribut keripik pisang dari yang tertinggi hingga terendah pada agroindustri KPS adalah expired date, rasa, label halal, kerenyahan, harga, dan kemasan, sedangkan pada agroindustri PD. AS dan KPKK adalah expired date, label halal, rasa, kerenyahan, kemasan, dan harga.

\section{Proses Pengambilan Keputusan}

Proses pengambilan keputusan pembelian adalah proses dimana konsumen benar-benar membeli produk. Proses pengambilan keputusan pembelian dilakukan bertahap dari sebelum pembelian aktual sampai dampak yang dirasakan setelah konsumsi. Menurut Kotler dan Keller (2009) ada lima tahapan proses pengambilan keputusan konsumendalam membeli keripik pisang padaagroindustri KPS, PD. AS, dan KPKK, yaitu pengenalan kebutuhan, pencarian informasi, evaluasi alternatif, keputusan pembelian, dan evalausi pasca pembelian.

Pada tahap pengenalan kebutuhan, alasan konsumen pada agroindustri KPS, PD. AS, dan KPKK berkunjung pertama kali karena adanya keinginan untuk mengonsumsi produk yang aman yaitu dengan adanya sertifikat halal pada produk keripik pisang. Keripik pisang pada agroindustri KPS, PD. AS, dan KPKK banyak diminati karena memiliki rasa yang enak dan aman. Selain itu, alasan konsumen di agroindustri KPS membeli keripik pisang adalah hanya sekedar ingin mencoba. Hal ini sejalan dengan Andela (2019) yang menyatakan bahwa konsumen pie pisang di YA dan JB banyak yang hanya sekedar ingin mencoba bagaimana rasa dari pie pisang. Konsumen juga banyak yang hobi mengonsumsi keripik pisang sebagai camilan. Konsumen merasa biasa saja jika tidak mengonsumsi keripik pisang, karena keripik pisang bukanlah makanan pokok atau utama.

Tahap pencarian informasi, konsumen yang terangsang akan kebutuhannya akan terdorong untuk melakukan pencarian berbagai informasi mengenai produk keripik pisang yang akan dibelinya dengan mempelajari ciri-ciri dari produk tersebut. Faktor utama yang membuat konsumen membeli keripik pisang pada agroindustri KPS, PD. AS, dan KPKK adalah karena sudah bersertifikat halal dan rasa keripik pisang yang ditawarkan oleh agroindustri. Konsumen mendapat pengaruh dari pihak lain untuk membeli dan mengonsumsi keripik pisang yaitu pengaruh dari keluarga.

Sumber informasi juga mempengaruhi konsumen dalam melakukan pencarian informasi mengenai produk keripik pisang yang akan dibeli. Konsumen pada agroindustri KPS, PD. AS, dan KPKK memperoleh sumber informasi dari mulut ke mulut. Sumber informasi dari mulut ke mulut memang dianggap sangat berperan dalam mempengaruhi konsumen untuk melakukan pembelian suatu produk. Hal ini tidak sejalan dengan penelitian yang dilakukan oleh Effendi, Astuti, dan Pratiwi (2015) yang menyatakan bahwa sebanyak 61 persen konsumen mengetahui produk keripik buah dari gerai oleh-oleh. Hal ini dikarenakan pusat untuk pembelian keripik buah adalah digerai oleh-oleh.

Pada tahap evaluasi alternatif konsumen berusaha memenuhi kebutuhan, mencari manfaat tertentu dari keripik pisang, dan memandang masingmasing produk sebagai sekumpulan atribut dengan kemampuan yang berbeda-beda dalam memberikan manfaat yang digunakan untuk memuaskan kebutuhan itu. Pada penelitian ini terdapat beberapa alasan konsumen berkunjung ke agroindustri KPS, PD. AS, dan KPKK. Sebagian besar konsumen memiliki alasan yang sama yaitu berkunjung ke agroindustri KPS, PD. AS, dan KPKK karena produk keripik pisang pada tiga toko 
ini halal dengan masing-masing persentase sebesar 50 persen pada KPS, 77 persen pada PD. AS, dan 57 persen pada KPKK. Produk yang halal tentu sangat penting bagi konsumen muslim saat ingin membeli dan mengonsumsi produk makanan, karena konsumen muslim diharuskan mengonsumsi makanan-makanan yang halal. Apabila stok keripik pisang habis, konsumen pada agroindustri KPS dan PD. AS memilih untuk membeli di toko lain yang juga sudah bersertifikat halal. Konsumen pada agroindustri KPKK memilih untuk membatalkan niat membeli jika stok keripik pisang habis. Hal ini sejalan dengan Kuswara (2013) yang menyatakan bahwa konsumen memutuskan untuk tidak jadi membeli lapis bogor apabila outlet yang dituju tutup atau stok habis. Konsumen juga sering membeli dan mengonsumsi produk keripik pisang di agroindustri lain dengan alasan mudah untuk memperolehnya dengan persentase masing-masing sebesar 67 persen pada KPS, 77 persen pada PD. AS, dan 43 persen pada KPKK.

Tahap keputusan pembelian adalah tindakan konsumen dalam mengambil keputusan mengenai produk yang dibeli, di mana membeli, dan bagaimana membelinya. Konsumen di agroindustri KPS paling banyak berkunjung tiga kali dalam satu tahun terakhir dengan persentase sebesar 39 persen, konsumen pada agroindustri PD. AS paling banyak berkunjung dua kali dalam satu tahun terakhir dengan persentase sebesar 46 persen, dan konsumen pada agroindustri KPKK paling banyak berkunjung empat kali dalam satu tahun terakhir dengan persentase sebesar 43 persen. Saat memutuskan untuk datang ke agroindustri KPS, PD. AS, dan KPKK sudah terencana oleh konsumen, karena konsumen sengaja ingin membeli keripik pisang yang sudah bersertifikat halal. Hal ini sejalan dengan penelitian yang dilakukan oleh Aeni, Widodo, dan Widodo (2017) yang menyatakan bahwa sebanyak 82,50 persen responden menyatakan bahwa pembelian keripik buah pertama kali adalah sudah terencana. Artinya, sebelum konsumen melakukan pembelian terlebih dahulu mereka mencari bekal informasi tentang keripik buah. Konsumen datang ke toko bersama dengan keluarga dan teman pada akhir pekan dan pulang kerja atau sekolah sekitar pukul 15.00-18.00 WIB.

Varian rasa yang disukai oleh konsumen pada agroindustri KPS, PD. AS, dan KPKK adalah rasa cokelat dengan persentase masing-masing sebesar 50 persen pada KPS, 54 persen pada PD. AS, dan 64 persen pada KPKK. Keripik pisang yang dibeli oleh konsumen sebagian besar memang sengaja dibeli untuk konsumsi sendiri sebagai camilan. Konsumen terakhir melakukan pembelian sekitar satu bulan yang lalu dengan persentase masingmasing sebesar 44 persen pada KPS, 46 persen pada PD. AS, dan 57 persen pada KPKK.

Tahap evaluasi pasca pembelian adalah tindakan konsumen dalam menilai keripik pisang yang telah dibelinya sudah memenuhi kebutuhannya atau belum (puas atau tidak puas). Konsumen sudah merasa puas terhadap produk keripik pisang yang ada pada agroindustri KPS, PD. AS, dan KPKK dengan persentase masing-masing sebesar 72 persen pada KPS, 54 persen pada PD. AS, dan 50 persen pada KPKK. Hal ini sejalan dengan Kabuli, Indriani, dan Situmorang (2018) yang menyatakan bahwa sebagian besar (97,92 persen) konsumen merasa puas setelah membeli dan mengosumsi yoghurt cair.

Konsumen yang merasa puas akan terdorong untuk melakukan pembelian ulang. Alasan konsumen sudah merasa puas terhadap keripik pisang karena rasanya yang enak. Faktor yang belum memuaskan konsumen KPS adalah kebersihan tempat dengan persentase sebesar 78 persen. Konsumen pada PD. AS belum merasa puas dengan ukuran keripik pisang dengan persentase sebesar 47 persen. Konsumen di KPKK merasa belum puas dengan harga yang ditawarkan, karena sebagian besar konsumen adalah mahasiswa harga yang diinginkan pasti yang murah dan sesuai dengan kantong mahasiswa. Terdapat beberapa atribut yang perlu mendapatkan perhatian dari pihak agroindustri adalah atribut kemasan pada KPS, atribut rasa pada PD. AS, atribut kemasan dan rasa pada KPKK.

\section{KESIMPULAN}

Proses sertifikasi halal yang dilakukan oleh LPPPOM MUI Provinsi Lampung pada agroindustri keripik pisang memiliki beberapa tahapan yang dilakukan secara online. Mulai dari registrasi secara online melalui web regs.elppommui.org, membayar registrasi, upload dokumen (data perusahaan, dokumen halal, data produk) di cerol, dilakukan audit oleh Tim Audit LPPOM MUI Provinsi Lampung, membayar akad, hasil audit kemudian masuk rapat fatwa. Setelah dinyatakan halal, LPPOM MUI Provinsi Lampung mengeluarkan sertifikat halal pada agroindustri keripik pisang. Peningkatan penjualan yang terjadi setelah agroindustri memperoleh sertifikat halal adalah terjadi peningkatan jumlah produksi dan 
omzet mencapai 40 persen pada agroindustri KPS, PD. AS, dan KPKK. Saat melakukan keputusan pembelian keripik pisang atribut halal sangat dipertimbangkan oleh konsumen. Setelah melakukan pembelian keripik pisang bersertifikat halal konsumen merasa puas dan mungkin akan melakukan pembelian ulang.

\section{DAFTAR PUSTAKA}

Aeni Y, Widodo, dan Widodo AS. 2017. Pengambilan Keputusan Konsumen dalam Pembelian Keripik Buah di Malang. AGRARIS: Journal of Agribusiness and Rural Development Research. http://repository.umy. ac.id/bitstream/handle/123456789/14417/12\% 20Naskah\%20publikasi.pdf?sequence $=12 \&$ is Allowed=y. [9 Oktober 2019].

Andela WE. 2019. Sikap, Pengambilan Keputusan dan Kepuasan Konsumen terhadap Agroindustri Pie Pisang di Kota Bandar Lampung. Skripsi. Universitas Lampung. Bandar Lampung.

Effendi M, Astuti R, dan Pratiwi NJ. 2015. Perilaku Konsumen dalam Keputusan Pembelian Keripik Buah (Studi Kasus Kota Malang). Prosiding Seminar Agroindustri dan Lokakarya Nasional FKPT-TPI. 133-138. http://tip.trunojoyo.ac.id/semnas/wpcontent/u ploads/B133-B138-Mas\%E2\%80\%99udEffendi_Unibraw.pdf. [4 Oktober 2019].

Ghozali I. 2002. Aplikasi Analisis Multivariate dengan Program SPSS. Badan PenerbitUndip. Semarang.
Kabuli KK, Indriani Y, dan Situmorang S. 2018. Analisis pengetahuan dan sikap konsumen dalam membeli yoghurt di Bandar Lampung. JIIA, 6 (2) : 196-204. http://jurnal.fp.unila.ac. id/index.php/JIA/article/view/2786/2332. [2 Oktober 2019].

Kotler P dan Keller. 2009. Manajemen Pemasaran. Jilid I Edisi ke 13. Erlangga. Jakarta.

Kuswara E. 2013. Analisis Perilaku dan Kepuasan dalam Proses Keputusan Pembelian Lapis Bogor Sangkuriang. Skripsi. IPB. Bogor. https://repository.ipb.ac.id/bitstream/handle/1 23456789/67664/H13eku.pdf?sequence $=1 \&$ is Allowed=y. [2 Oktober 2019].

Lembaga Pengkajian Pangan, Obat-Obatan dan Kosmetika Majelis Ulama Indonesia. 2014. Sertifikasi Halal. LPPOM MUI. Jakarta.http://www.halalmui.org/mui14/. [14 Oktober 2019].

Soekartawi. 2005. Agribisnis dalam Perspektif Sosial Ekonomi. Raja Grafindo Persada. Jakarta.

Sufren dan Natanael Y. 2013. Mahir Menggunakan SPSS Secara Otodidak. Elex Media Komputindo. Jakarta.

Sugiyono. 2009. Metode Penelitian Kuantitatif, Kualitatif dan $R \& D$. Alfabeta. Bandung.

Sumarwan U. 2011. Perilaku Konsumen. Ghalia Indonesia. Jakarta.

Swastha B. 2005. Manajemen Penjualan. BPFE. Yogyakarta. 